\title{
Challenges and opportunities for T-cell-mediated strategies to eliminate HIV reservoirs
}

\author{
Mark A. Brockman ${ }^{1,2 *}$, R. Brad Jones ${ }^{3}$ and Zabrina L. Brumme ${ }^{1,2}$ \\ ${ }^{1}$ Faculty of Health Sciences, Simon Fraser University, Burnaby, BC, Canada, ${ }^{2}$ BC Centre for Excellence in HIVIAIDS, \\ Vancouver, BC, Canada, ${ }^{3}$ Department of Microbiology, Immunology and Tropical Medicine, The George Washington \\ University, Washington, DC, USA
}

OPEN ACCESS

Edited by:

Lucy Dorrell,

University of Oxford, UK

Reviewed by:

Paul Goepfert,

University of Alabama at Birmingham,

USA

Michael Betts,

University of Pennsylvania, USA Stephen Kent,

University of Melbourne, Australia

*Correspondence:

Mark A. Brockman,

Faculty of Health Sciences, Simon

Fraser University, 8888 University

Drive, Burnaby, BC,

Canada, V5A 156

mark_brockman@sfu.ca

Specialty section:

This article was submitted to HIV and

AIDS, a section of the

journal Frontiers in Immunology

Received: 16 July 2015

Accepted: 17 September 2015

Published: 02 October 2015

Citation:

Brockman MA, Jones RB and

Brumme ZL (2015) Challenges and opportunities for T-cell-mediated strategies to eliminate HIV reservoirs.

Front. Immunol. 6:506.

doi: 10.3389/fimmu.2015.00506
HIV's ability to establish latent reservoirs of reactivation-competent virus is the major barrier to cure. "Shock and kill" methods consisting of latency-reversing agents (LRAs) followed by elimination of reactivating cells through cytopathic effects are under active development. However, the clinical efficacy of LRAs remains to be established. Moreover, recent studies indicate that reservoirs may not be reduced efficiently by either viral cytopathic or $\mathrm{CD}^{+} \mathrm{T}$-cell-mediated mechanisms. In this perspective, we highlight challenges to T-cell-mediated elimination of HIV reservoirs, including characteristics of responding $T$ cells, aspects of the cellular reservoirs, and properties of the latent virus itself. We also discuss potential strategies to overcome these challenges by targeting the antiviral activity of $T$ cells toward appropriate viral antigens following latency.

Keywords: HIV latency, T cells, CTL escape, immune evasion, immune-based therapy

\section{Introduction}

Combination antiretroviral therapy (cART) durably suppresses HIV, but the virus' ability to persist in a quiescent state within cellular reservoirs prevents its eradication from the body. cART must therefore be maintained for life. The "Berlin patient" was cured of HIV following a stem cell transplant from a CCR $5 \Delta 32$ homozygous donor that repopulated his immune system with virus-resistant cells (1), indicating that eradication is possible. But, safer and scalable strategies are clearly needed.

Latent HIV-infected cells produce very low levels of viral RNA and proteins and thus remain largely hidden from cellular immunity. Reactivation induces viral protein expression and virion production, which should make cells susceptible to viral cytopathic effects and immune targeting. However, low basal reactivation rates, maintenance of latent HIV-infected cells through homeostatic proliferation (2-6), and survival of cells following reactivation (7) ensure that reservoirs persist after many years on cART $(8,9)$. "Shock-and-kill" methods to reactivate latent cells ("shock") so they can be eliminated through host or viral cytopathic effects ("kill") (10) have been proposed to achieve clinical HIV remission ("functional cure") or reservoir elimination ("sterilizing cure"). To avoid viral spread and establishment of new reservoirs, "shock-and-kill" is conducted in the presence of cART - but clinical successes have been limited. While identification of latency-reversing agents (LRA) supports the feasibility of this approach, elimination of reactivated cells poses a major barrier

Abbreviations: CAR, chimeric antigen receptor; cART, combination antiretroviral therapy; CTL, cytotoxic T lymphocyte; HDACi, histone deacetylase inhibitor; LRA, latency-reversing agent; SAHA, suberoylanilide hydroxamic acid; TCR, T-cell receptor. 
$(11,12)$. Here, we highlight challenges in this area, including limited clinical performance of LRAs, resistance of reservoirs to host and viral cytopathic effects, dysfunction of cytotoxic T lymphocytes (CTL), and viral immune evasion mechanisms. We also discuss strategies to enhance T-cell activity and develop T-cellbased therapeutics. For a review of antibody-mediated strategies for HIV eradication, please see Lee et al. in this series (13).

\section{Limitations of Latency-Reversing Agents}

Latently infected cells can be induced to express HIV RNA and proteins using non-specific activating agents, such as phytohemagglutinin or anti-CD3/CD28 antibodies in the case of CD4 ${ }^{+}$ $\mathrm{T}$ cells, but toxicity from cellular proliferation and inflammatory cytokines precludes their use in vivo. Instead, multiple classes of LRAs, including histone deacetylase inhibitors (HDACi), bromodomain inhibitors, protein kinase $\mathrm{C}$ agonists, cytokines such as IL-2 and IL-15, and others, have been identified that induce latent cells to produce viral RNA, proteins, and virions without causing global T-cell activation [for reviews, see Ref. (14, 15)]. However, challenges remain. Due to the rarity of latent cells in vivo [approximately 1 per $10^{6}$ resting $\mathrm{CD}^{+} \mathrm{T}$ cells $\left.(16,17)\right]$, LRA discovery generally relies on cell lines that may not reflect reservoir complexity (18). Indeed, while the major HIV reservoir is resting $\mathrm{CD}^{+} \mathrm{T}$ cells (19), HIV persists in other cell types, tissues, and anatomical compartments (20) that remain largely untested using LRAs. Moreover, since latency is maintained via numerous mechanisms, including regulation of heterochromatic structure (21) and host factors required for gene transcription (22), LRAs with distinct mechanisms of action may need to be combined to maximize reactivation frequency or magnitude (23). Combination approaches may also benefit from reduced toxicity due to lower doses of individual agents. Toward this goal, some LRAs show synergistic ability to reactivate $\operatorname{HIV}$ in vitro $(24,25)$.

In vivo disruption of HIV latency using LRAs has been difficult to achieve. Administration of gamma-chain cytokine IL-7 generated "blips" of viremia in cART-treated individuals (26); however, this may result from productively infected cells rather than from reservoir reactivation $(27,28)$. More recently, three HDACi have exhibited limited ability to disrupt latency in vivo. Specifically, elevated levels of intracellular unspliced gag RNA - but not protein - were observed following administration of vorinostat (suberoylanilide hydroxamic acid, SAHA) (29), while panobinostat (30) and romidepsin (31) produced transient low-level increases in plasma viremia. While supporting the "shock" strategy, none of these agents appreciably reduced reservoir size. Moreover, cells became refractory to HDACi treatment following serial dosing in vivo $(32,33)$. Efforts to identify LRAs (or combinations) with greater in vivo potency without significant toxicity thus remain paramount.

\section{Challenges for T-Cell-Mediated Killing of HIV Reservoirs}

Cytotoxic T lymphocytes play a crucial role in containing HIV (34-36). Determinants of CTL-mediated reservoir elimination under cART, however, may be distinct from those involved in viremia control during untreated infection. For example, whereas targeting of conserved viral epitopes - where escape is impossible or confers a substantial fitness cost (37-41) - may be desirable for natural or vaccine-induced HIV control by CTL $(42,43)$, this may not be critical in the context of latency reactivation since immune escape mutations will not emerge under cART. In addition, while rapid CTL-mediated killing of infected cells (i.e., before progeny is produced) might be optimal during untreated infection (44-46), prevention of viral spread by cART may allow effective targeting of viral epitopes with slower presentation kinetics. Furthermore, in untreated infection, a combination of cytolytic and non-cytolytic (e.g., interferon gamma, MIP-1, or RANTES) mechanisms (47) contain HIV, but only cytolytic activity is likely to contribute to reservoir reduction. Thus, while high-avidity CTL are beneficial for natural control of infection (48-50), they may be even more crucial to eliminate reservoirs, particularly if LRAs induce only low viral antigen levels. But some lessons from natural infection remain relevant. For example, HIV elite controllers (rare individuals who spontaneously suppress HIV plasma viremia to $<50$ RNA copies/mL in the absence of cART) harbor significantly lower proviral DNA levels, underscoring their potential utility to inform research toward a functional cure (51).

\section{Resistance of Reservoirs to Cytopathic Effects}

Consistent with their longevity in vivo, latently infected resting $\mathrm{CD} 4^{+} \mathrm{T}$ cells resist host and viral cytopathic effects following reactivation. Ex vivo treatment of cells with SAHA had no discernable effect on replication-competent HIV load (7), highlighting the limited ability of HDACis alone to eliminate HIV (52). Inherent features of resting $\mathrm{CD} 4^{+} \mathrm{T}$ cells, such as enhanced expression of survival factors or changes in metabolic state $(53,54)$, may also enhance their resilience. Furthermore, reactivating cells express viral proteins at low levels $(55,56)$, which may limit virus-induced disruption of critical host cell functions and reduce the chance of a "natural" death. This would also impair viral epitope presentation by HLA class I to CTL, impairing immune-mediated clearance. Strategies to modulate cellular metabolism (53) or apoptosis (57) may hasten cell death due to viral cytopathic effects or immunemediated killing. Differences in antigen processing among cell types permissive to HIV (58-61) that alter the sequence, kinetics, or distribution of epitopes may also have cell-type-dependent effects on CTL recognition. Research on antigen processing and presentation in reactivating cells to identify optimal CTL epitopes should be a priority.

\section{Poor Antiviral Cytotoxic T-Cell Activity}

Cytotoxic T lymphocytes from cART-treated individuals display limited ex vivo cytolytic activity against latent $\mathrm{CD} 4^{+} \mathrm{T}$ cells reactivated using SAHA, although killing can be enhanced by restimulating CTL with viral peptides (7). This indicates that antiviral cells are present in blood, but cannot respond effectively - perhaps due to lack of perforin or granzyme expression $(62,63)$. Such nonreactivity may result from prolonged absence of antigen due to cART, triggering establishment of resting central memory $\mathrm{T}$ cells that display lower cytolytic potential, particularly in lymphoid tissues where latent HIV is likely to reside (64). Limited T-cell trafficking and/or cytolytic function in lymph nodes may also be 
a concern in chronic HIV-infected individuals on cART $(65,66)$. Moreover, CTL exhaustion, characteristic of chronic infection and manifested by induction of "immune checkpoint inhibitors" PD-1, CTLA-4, and other inhibitory receptors $(67,68)$, may play a role. In any case, short-term expansion may select or amplify CTL with greater reactivity. Notably, elite controllers demonstrate better ability to eliminate latent HIV-infected cells ex vivo (7). This is consistent with maintenance of effector memory CTL by controllers (69) and suggests that such cells may be necessary to immediately recognize reactivating targets. Antibodies that block PD-1 (i.e., nivolumab) or CTLA-4 (i.e., ipilimumab) improve in vivo CTL responses against tumor-derived antigens (70), and similar approaches are being tested for HIV (71). Although studies of chronic SIV-infected rhesus macaques indicated that PD-1 blockade enhanced antiviral immunity and reduced plasma viremia $(72,73)$, additional human trials will be critical to evaluate this strategy (74).

Unintended negative consequences of LRAs may also hinder reservoir elimination. Immunomodulatory effects of HDACis on antigen presentation and immune cell signaling have been reported $(75,76)$. Moreover, treatment with HDACis (romidepsin and panobinostat) at clinically relevant doses impaired CTL cytokine production and cytolytic responses toward HIV target cells (77). The effects of other LRAs on immune function have not been reported and should be assessed during pre-clinical testing.

\section{Viral Evasion from T-Cell Immunity}

Cytotoxic T lymphocyte killing requires recognition of peptides presented in complex with HLA class I on the infected cell surface. As such, the ability of HIV to evade CTL through mutational escape (78) and Nef-mediated downregulation of HLA class I (79) are highly relevant to reservoir elimination efforts.

HIV eludes CTL by altering the sequence of viral epitopes in a manner that is predictable based on the HLA class I alleles expressed by the host $(80,81)$. As immune escape $(82-86)$ and seeding of the reservoir (87) begin in early infection, the presence of escaped epitopes in latently infected cells is a major barrier. Indeed, mutations in proviral sequences from cART-treated individuals reduced CTL recognition of these cells following reactivation $(88,89)$. Ongoing reservoir seeding poses additional challenges. While plasma HIV RNA sequences reflect contemporary viral forms that have survived multiple within-host immune bottlenecks, the reservoir is likely to comprise a genetically heterogeneous population reflecting multiple descendant lineages from the transmitted/founder viral strain, including extinct ones. Thus, the latent pool is likely to include escaped and non-escaped (archival) forms of the same epitope [though it has been noted that the majority of reservoirs carry some escape mutations (88)]. Eliminating such a heterogeneous target may require revitalization of CTL against non-escaped epitopes as well as elicitation or expansion of CTL capable of responding to more diverse sequences including escape mutations (11) and subdominant epitopes (90). These considerations are somewhat distinct from vaccine strategies that traditionally focus on conserved viral elements $(42,43)$. Importantly, in addition to improving clinical outcomes (91-93) and limiting transmission (94, 95), early cART reduces reservoir size and diversity (96-99), underscoring "seek, test, and treat" approaches to improve the odds of cure. Addressing reservoir diversity will nevertheless be important, as most individuals initiate cART after reservoirs encoding escape mutations are established.

Downregulation of HLA-A and HLA-B molecules by HIV-1 Nef represents another key CTL evasion strategy $(100,101)$. While no studies have explicitly examined the impact of Nef-mediated HLA-downregulation in the context of latency reversal, early expression of Nef (before Gag, Pol, and Env) (79) will presumably allow it to function similarly in reactivating cells. As such, identifying early viral epitopes presented before Nef acts $(102,103)$ may be useful for eradication. In contrast to untreated infection, where Gag epitopes from incoming virions can be presented to CTL prior to Nef-mediated HLA downregulation (104), the earliest viral peptides presented following reactivation will be derived from accessory/regulatory proteins (Tat, Rev, Nef) expressed by the integrated provirus. CTL targeting these proteins are not generally associated with control in untreated HIV infection (105), but may nevertheless be beneficial (106), particularly for Tat (107). Other Nef features may also be relevant. As HLA-B alleles display some resistance to Nef-mediated downregulation compared to A alleles (108), HLA-B-restricted CTL may be better able to recognize reactivating cells [though one study reported no difference when cells were restimulated ex vivo with a small number of A- versus B-restricted peptides (88)]. HLA-C is not downregulated by Nef $(109,110)$ and HLA-C expression correlates with HIV control (111); thus C-restricted epitopes may be attractive targets. In addition, Nef's ability to downregulate CD4 may contribute to reservoir evasion from antibody-dependent cellular cytotoxicity $(13,112-114)$. Notably, patient-derived Nef sequences differ in their ability to downregulate HLA class I and CD4 $(115,116)$, and these Nef functions can be attenuated through within-host viral adaptation to CTL (117), indicating that Nef's ability to modulate HIV latency may differ based on viral and immunogenetic factors unique to each host. Small molecule inhibitors of Nef (118) might enhance the visibility of cells following reactivation.

\section{Targeting Reservoir Diversity}

Substantial interindividual heterogeneity in reservoir size and sequence (i.e., early versus late cART, prevalence of escape mutations) and host CTL responses (i.e., HLA type, dominant epitopes targeted, exhaustion) highlight the complexity of HIV elimination and imply that a "one-size-fits-all" approach may not be fully successful. T-cell-based therapies tailored, in part, to features of individual patients may help to move us toward approaches for HIV cure.

\section{Genetic Characterization of the Reservoir}

Evaluation of reservoirs focuses mainly on quantifying proviral DNA, RNA transcripts, and viral outgrowth (119). Replicative competence is also important, although the high levels of genedeleted or hypermutated sequences seen in latent reservoirs may contribute to inflammation (52). As such, genetic analyses of latent HIV sequences as well as host factors (i.e., HLA) (88) may pave the way for more personalized immunotherapeutic 
strategies: next-generation sequencing technologies will be particularly useful in this regard. At the most basic level, such approaches may identify non-mutated CTL epitopes that can serve as immune targets, analogous to use of HIV drug resistance genotyping to guide cART $(120,121)$. Characterization of latent HIV diversity may shed light on another key question - that of elucidating the chronology of reservoir establishment in different cell types and tissues. As CTL escape mutations are highly reproducible in terms of HIV genomic locations $(41,80,81)$ and selection kinetics $(84-86,122,123)$, they can provide a crude estimate of the relative age of reservoirs. While this has been examined in the context of SIV where founder viral sequence and inoculation date are known $(124,125)$, refined estimates of HIV reservoir age in humans may require more advanced phylogenetic approaches. The problem of dating reservoir sequences within an individual's infection history is similar to that of dating organismal sequences of unknown age in the context of macroevolution [i.e., ancient DNA (126)] or in the case of HIV, specimens archived from historic eras $(127,128)$. In the latter case, heterochronous HIV sequences (i.e., those sampled from different individuals over the epidemic's course) are used to calibrate viral evolutionary rates to calendar time using Bayesian (126) or root-to-tip regression (127) approaches, allowing the estimation of sampling times (tip-ages) for sequences of unknown age. Similarly, within-host plasma HIV RNA sequences sampled longitudinally from a given individual could be used to calibrate a host-specific HIV evolutionary rate that could be used to infer the date of establishment of individual reservoir sequences (129). Such analyses may be beneficial to retroactively investigate "partial" successes using shock-and-kill (e.g., to investigate whether the age of a reservoir predicts its potential for reactivation or CTL elimination).

\section{Therapeutic Vaccines}

Knowing that an epitope is present in the reservoir is only the first step. Although no therapeutic vaccine has succeeded in suppressing HIV viremia long-term, there is renewed interest to couple vaccines with LRAs and cART for additive effects (130). HIV persistence in tissues beyond the mucosa and lymphatic system, and strategies to enhance CTL patrol of these areas, represent major challenges. For example, T follicular helper cells located in B-cell follicles of lymph nodes may be a major reservoir (131-133); whole-body imaging of SIV-infected rhesus macaques revealed ongoing replication in the respiratory tract and lung tissue during cART (134), identifying these as potential sanctuary sites. Of note, a Phase II trial examining Tat as a therapeutic vaccine target demonstrated restoration of immune cells (including effector memory CD8 ${ }^{+} \mathrm{T}$ cells) and reduction of proviral DNA in blood (107); similar studies to assess other early viral protein targets (i.e., Rev and Nef) are also warranted.

Vaccine delivery methods are another consideration. Replication-competent and replication-defective viral vectors, nucleic acids, proteins, and various adjuvants have been tested in the context of HIV vaccines (135). Recently, a replicationcompetent simian cytomegalovirus vector expressing T-cell antigens has shown promise in a rhesus macaque model (136). While this vaccine did not generally prevent SIV infection, animals cleared viral RNA and DNA from plasma and tissues over the course of 1-2 years without cART (137). Although the mechanism of clearance is unknown, the vector's ability to maintain effector memory CTL, including those targeting noncanonical HLA class II and HLA-E-restricted epitopes, is likely to play a role $(136,138)$. Regardless of the vector used, CTL elicited by a vaccine must be cytolytic and capable of trafficking to sites where HIV resides.

\section{T-Cell-Based Therapies}

Advances in cancer treatment, including adoptive transfer of tumor infiltrating lymphocytes and antigen-specific T-cell receptor (TCR) gene therapy (139), have reinvigorated the field of T-cell-based therapies. Cancer and HIV treatment, however, differ in key respects, risk/benefit considerations being one. Support for immunotherapeutic approaches remains strong in the context of limited life expectancies and lack of alternative therapies for certain cancers, but new HIV treatments must meet a high barrier for implementation due to the potency and safety of cART. Nevertheless, the lack of serious adverse events in recent cancer immunotherapy trials bodes well for testing such approaches for HIV cure (140-142).

Adoptive therapy using autologous virus-specific T cells is not new to HIV (143), but studies have thus far been unsuccessful. Over the past 20 years, several groups have attempted ex vivo expansion and reinfusion of patients' own CTL (144-148). Limitations of these trials, including inefficient engraftment or survival of cells and lack of cART, are now addressable using optimized methods and improved treatment options. Transfer of autologous tumor infiltrating T cells is used routinely for some cancers $(149,150)$. Moreover, successful expansion of HIV-specific CTL from cARTtreated individuals that display ex vivo cytolytic activity against autologous reservoir cells $(89,151)$ indicates that newer adoptive T-cell strategies may demonstrate improved HIV efficacy, particularly if they can be coupled with LRAs.

Gene therapy approaches represent another possible avenue. Modification of CTL to express a heterologous TCR can redirect cells toward a specific antigen. Several strategies have been employed (140, 149), including native (unmodified) TCRs, affinity-enhanced TCRs, and "chimeric" antigen receptors (CAR) that typically encode the antigen-binding domain of immunoglobulin linked to an intracellular signaling domain such as CD3zeta. These methods are being assessed for various cancers and they are in earlier stage development for HIV - with several reports demonstrating antiviral activity in vitro or in small animal models. By reprogramming hematopoietic stem cells to express a TCR against the HLA-A*02-restricted Gag SL9 epitope (SLYNTVATL), Kitchen et al. (152) suppressed HIV viremia and reduced proviral DNA loads in a humanized mouse model. CTL have also been engineered to express HIV-specific CARs, including those targeting HIV gp120-expressing cells $(153,154)$. In addition, gene therapy may allow reprogramming of other critical CTL functions, including cytotoxicity or lymphoid trafficking potential. Similarly, combining gene therapy approaches with other immune modulators (such as blockade of checkpoint inhibitors) could provide added benefits. As a note of caution, clinical trials using an affinity-enhanced TCR specific for Gag SL9 (155) were canceled when severe toxicity was observed for 
a similar product against melanoma tumor antigen (156). In vivo safety thus remains a concern, but these methods offer highly flexible strategies to target HIV reservoirs.

\section{Conclusion}

Extraordinary progress is being made to understand the molecular mechanisms of HIV latency and to discover viral reactivation strategies. Overcoming barriers to eliminate latent cells will be critical for shock and kill strategies to succeed, and many important issues remain. What viral epitopes are presented efficiently by reactivating cells? Is antigen presentation affected by LRAs? Does Nef modulate the sensitivity of reactivating cells to CTL killing? Can therapeutic vaccines enhance reservoir targeting? Will T-cell-based therapeutics be safe and effective? Answers to these and other questions will guide future directions in this field

\section{References}

1. Hutter G, Nowak D, Mossner M, Ganepola S, Mussig A, Allers K, et al. Longterm control of HIV by CCR5 delta32/delta32 stem-cell transplantation. $N$ Engl J Med (2009) 360:692-8. doi:10.1056/NEJMoa0802905

2. Buzon MJ, Sun H, Li C, Shaw A, Seiss K, Ouyang Z, et al. HIV-1 persistence in CD4+ T cells with stem cell-like properties. Nat Med (2014) 20:139-42. doi: $10.1038 / \mathrm{nm} .3445$

3. Maldarelli F, Wu X, Su L, Simonetti FR, Shao W, Hill S, et al. HIV latency. Specific HIV integration sites are linked to clonal expansion and persistence of infected cells. Science (2014) 345:179-83. doi:10.1126/science.1254194

4. Wagner TA, McLaughlin S, Garg K, Cheung CY, Larsen BB, Styrchak S, et al. HIV latency. Proliferation of cells with HIV integrated into cancer genes contributes to persistent infection. Science (2014) 345:570-3. doi:10.1126/ science. 1256304

5. Cohn LB, Silva IT, Oliveira TY, Rosales RA, Parrish EH, Learn GH, et al. HIV-1 integration landscape during latent and active infection. Cell (2015) 160:420-32. doi:10.1016/j.cell.2015.01.020

6. von Stockenstrom S, Odevall L, Lee E, Sinclair E, Bacchetti P, Killian M, et al. Longitudinal genetic characterization reveals that cell proliferation maintains a persistent HIV type 1 DNA pool during effective HIV therapy. J Infect Dis (2015) 212:596-607. doi:10.1093/infdis/jiv092

7. Shan L, Deng K, Shroff NS, Durand CM, Rabi SA, Yang HC, et al. Stimulation of HIV-1-specific cytolytic T lymphocytes facilitates elimination of latent viral reservoir after virus reactivation. Immunity (2012) 36:491-501. doi:10.1016/j.immuni.2012.01.014

8. Crooks AM, Bateson R, Cope AB, Dahl NP, Griggs MK, Kuruc JD, et al. Precise quantitation of the latent HIV-1 reservoir: implications for eradication strategies. J Infect Dis (2015). doi:10.1093/infdis/jiv218

9. Siliciano JD, Kajdas J, Finzi D, Quinn TC, Chadwick K, Margolick JB, et al. Long-term follow-up studies confirm the stability of the latent reservoir for HIV-1 in resting CD4+ T cells. Nat Med (2003) 9:727-8. doi:10.1038/ $\mathrm{nm} 880$

10. Hamer DH. Can HIV be cured? Mechanisms of HIV persistence and strategies to combat it. Curr HIV Res (2004) 2:99-111. doi:10.2174/1570162043484915

11. Marsden MD, Zack JA. Double trouble: HIV latency and CTL escape. Cell Host Microbe (2015) 17:141-2. doi:10.1016/j.chom.2015.01.008

12. Shan L, Siliciano RF. From reactivation of latent HIV-1 to elimination of the latent reservoir: the presence of multiple barriers to viral eradication. Bioessays (2013) 35:544-52. doi:10.1002/bies.201200170

13. Lee WS, Parsons MS, Kent SJ, Lichtfuss M. Can HIV-1-specific ADCC assist the clearance of reactivated latently infected cells? Front Immunol (2015) 6:265. doi:10.3389/fimmu.2015.00265

14. Xing S, Siliciano RF. Targeting HIV latency: pharmacologic strategies toward eradication. Drug Discov Today (2013) 18:541-51. doi:10.1016/j. drudis.2012.12.008

15. Archin NM, Margolis DM. Emerging strategies to deplete the HIV reservoir. Curr Opin Infect Dis (2014) 27:29-35. doi:10.1097/QCO.0000000000000026 and may ultimately determine whether we prevail in the quest to cure HIV.

\section{Acknowledgments}

Research in the laboratories of $\mathrm{MB}$ and $\mathrm{ZB}$ is supported by The Canadian HIV Cure Enterprise Team Grant (HIG-133050) from the Canadian Institutes of Health Research in partnership with the Canadian Foundation for AIDS Research and the International AIDS Society. MB holds a CRC (Tier 2) position at Simon Fraser University, funded by the Canada Research Chairs program. RBJ is a Junior Investigator of the Ontario HIV Treatment Network and also gratefully acknowledges financial support from the GenerationCure initiative through the American Foundation for AIDS Research (amfAR). ZB holds a Scholar Award from the Michael Smith Foundation for Health Research.

16. Chun TW, Stuyver L, Mizell SB, Ehler LA, Mican JA, Baseler M, et al Presence of an inducible HIV-1 latent reservoir during highly active antiretroviral therapy. Proc Natl Acad Sci U S A (1997) 94:13193-7. doi:10.1073/ pnas.94.24.13193

17. Finzi D, Hermankova M, Pierson T, Carruth LM, Buck C, Chaisson RE, et al. Identification of a reservoir for HIV-1 in patients on highly active antiretroviral therapy. Science (1997) 278:1295-300. doi:10.1126/science.278.5341.1295

18. Bullen CK, Laird GM, Durand CM, Siliciano JD, Siliciano RF. New ex vivo approaches distinguish effective and ineffective single agents for reversing HIV-1 latency in vivo. Nat Med (2014) 20:425-9. doi:10.1038/nm.3489

19. Chavez L, Calvanese V, Verdin E. HIV latency is established directly and early in both resting and activated primary CD4 T cells. PLoS Pathog (2015) 11:e1004955. doi:10.1371/journal.ppat.1004955

20. Gray LR, Roche M, Flynn JK, Wesselingh SL, Gorry PR, Churchill MJ. Is the central nervous system a reservoir of HIV-1? Curr Opin HIV AIDS (2014) 9:552-8. doi:10.1097/COH.0000000000000108

21. Lusic M, Giacca M. Regulation of HIV-1 latency by chromatin structure and nuclear architecture. J Mol Biol (2015) 427:688-94. doi:10.1016/j. jmb.2014.07.022

22. Mbonye U, Karn J. Transcriptional control of HIV latency: cellular signaling pathways, epigenetics, happenstance and the hope for a cure. Virology (2014) 454-455:328-39. doi:10.1016/j.virol.2014.02.008

23. Spina CA, Anderson J, Archin NM, Bosque A, Chan J, Famiglietti M, et al. An in-depth comparison of latent HIV-1 reactivation in multiple cell model systems and resting CD4+ T cells from aviremic patients. PLoS Pathog (2013) 9:e1003834. doi:10.1371/journal.ppat.1003834

24. Laird GM, Bullen CK, Rosenbloom DI, Martin AR, Hill AL, Durand CM, et al. Ex vivo analysis identifies effective HIV-1 latency-reversing drug combinations. J Clin Invest (2015) 125:1901-12. doi:10.1172/JCI80142

25. Dar RD, Hosmane NN, Arkin MR, Siliciano RF, Weinberger LS. Screening for noise in gene expression identifies drug synergies. Science (2014) 344:1392-6. doi:10.1126/science. 1250220

26. Sereti I, Dunham RM, Spritzler J, Aga E, Proschan MA, Medvik K, et al. IL-7 administration drives T cell-cycle entry and expansion in HIV-1 infection. Blood (2009) 113:6304-14. doi:10.1182/blood-2008-10-186601

27. Imamichi H, Degray G, Asmuth DM, Fischl MA, Landay AL, Lederman MM, et al. HIV-1 viruses detected during episodic blips following interleukin-7 administration are similar to the viruses present before and after interleukin-7 therapy. AIDS (2011) 25:159-64. doi:10.1097/QAD.0b013e328340a270

28. Vandergeeten C, Fromentin R, DaFonseca S, Lawani MB, Sereti I, Lederman $\mathrm{MM}$, et al. Interleukin-7 promotes HIV persistence during antiretroviral therapy. Blood (2013) 121:4321-9. doi:10.1182/blood-2012-11-465625

29. Archin NM, Liberty AL, Kashuba AD, Choudhary SK, Kuruc JD, Crooks $\mathrm{AM}$, et al. Administration of vorinostat disrupts HIV-1 latency in patients on antiretroviral therapy. Nature (2012) 487:482-5. doi:10.1038/nature11286

30. Rasmussen TA, Tolstrup M, Brinkmann CR, Olesen R, Erikstrup C, Solomon A, et al. Panobinostat, a histone deacetylase inhibitor, for latent-virus reactivation in HIV-infected patients on suppressive antiretroviral therapy: a phase 
1/2, single group, clinical trial. Lancet HIV (2014) 1:e13-21. doi:10.1016/ S2352-3018(14)70014-1

31. Søgaard OS, Graversen ME, Leth S, Olesen R, Brinkmann CR, Nissen SK, et al. The Depsipeptide Romidepsin Reverses HIV-1 Latency In Vivo. PLoS Pathog (2015) 11: e1005142. doi:10.1371/journal.ppat.1005142

32. Archin NM, Bateson R, Tripathy MK, Crooks AM, Yang KH, Dahl NP, et al. HIV-1 expression within resting CD4+ T cells after multiple doses of vorinostat. J Infect Dis (2014) 210:728-35. doi:10.1093/infdis/jiu155

33. Del Prete GQ, Shoemaker R, Oswald K, Lara A, Trubey CM, Fast R, et al. Effect of suberoylanilide hydroxamic acid (SAHA) administration on the residual virus pool in a model of combination antiretroviral therapy-mediated suppression in SIVmac239-infected Indian rhesus macaques. Antimicrob Agents Chemother (2014) 58:6790-806. doi:10.1128/AAC.03746-14

34. Borrow P, Lewicki H, Hahn BH, Shaw GM, Oldstone MB. Virus-specific CD8+ cytotoxic T-lymphocyte activity associated with control of viremia in primary human immunodeficiency virus type 1 infection. J Virol (1994) 68:6103-10.

35. Carrington M, Walker BD. Immunogenetics of spontaneous control of HIV. Annu Rev Med (2012) 63:131-45. doi:10.1146/annurev-med-062909-130018

36. Koup RA, Safrit JT, Cao Y, Andrews CA, McLeod G, Borkowsky W, et al. Temporal association of cellular immune responses with the initial control of viremia in primary human immunodeficiency virus type 1 syndrome. $J$ Virol (1994) 68:4650-5.

37. Batorsky R, Sergeev RA, Rouzine IM. The route of HIV escape from immune response targeting multiple sites is determined by the cost-benefit tradeoff of escape mutations. PLoS Comput Biol (2014) 10:e1003878. doi:10.1371/ journal.pcbi. 1003878

38. Troyer RM, McNevin J, Liu Y, Zhang SC, Krizan RW, Abraha A, et al. Variable fitness impact of HIV-1 escape mutations to cytotoxic T lymphocyte (CTL) response. PLoS Pathog (2009) 5:e1000365. doi:10.1371/journal. ppat. 1000365

39. Brockman MA, Schneidewind A, Lahaie M, Schmidt A, Miura T, Desouza I, et al. Escape and compensation from early HLA-B57-mediated cytotoxic T-lymphocyte pressure on human immunodeficiency virus type $1 \mathrm{Gag}$ alter capsid interactions with cyclophilin A. J Virol (2007) 81:12608-18. doi:10.1128/JVI.01369-07

40. Schneidewind A, Brockman MA, Yang R, Adam RI, Li B, Le Gall S, et al. Escape from the dominant HLA-B27-restricted cytotoxic T-lymphocyte response in Gag is associated with a dramatic reduction in human immunodeficiency virus type 1 replication. J Virol (2007) 81:12382-93. doi:10.1128/ JVI.01543-07

41. Carlson JM, Brumme CJ, Martin E, Listgarten J, Brockman MA, Le AQ, et al. Correlates of protective cellular immunity revealed by analysis of population-level immune escape pathways in HIV-1. J Virol (2012) 86:13202-16. doi:10.1128/JVI.01998-12

42. Rolland M, Nickle DC, Mullins JI. HIV-1 group M conserved elements vaccine. PLoS Pathog (2007) 3:e157. doi:10.1371/journal.ppat.0030157

43. Hanke T. Conserved immunogens in prime-boost strategies for the next-generation HIV-1 vaccines. Expert Opin Biol Ther (2014) 14:601-16. doi:10.151 7/14712598.2014.885946

44. Migueles SA, Connors M. Success and failure of the cellular immune response against HIV-1. Nat Immunol (2015) 16:563-70. doi:10.1038/ni.3161

45. Migueles SA, Laborico AC, Shupert WL, Sabbaghian MS, Rabin R, Hallahan $\mathrm{CW}$, et al. HIV-specific CD8+ T cell proliferation is coupled to perforin expression and is maintained in nonprogressors. Nat Immunol (2002) 3:1061-8. doi:10.1038/ni845

46. Saez-Cirion A, Lacabaratz C, Lambotte O, Versmisse P, Urrutia A, Boufassa F, et al. HIV controllers exhibit potent CD8 T cell capacity to suppress HIV infection ex vivo and peculiar cytotoxic T lymphocyte activation phenotype. Proc Natl Acad Sci U S A (2007) 104:6776-81. doi:10.1073/pnas.0611244104

47. Saksena NK, Wu JQ, Potter SJ, Wilkinson J, Wang B. Human immunodeficiency virus interactions with CD8+ T lymphocytes. Curr HIV Res (2008) 6:1-9. doi:10.2174/157016208783572008

48. Appay V, Iglesias MC. Antigen sensitivity and T-cell receptor avidity as critical determinants of HIV control. Curr Opin HIV AIDS (2011) 6:157-62. doi:10.1097/COH.0b013e3283453dfd

49. Mothe B, Llano A, Ibarrondo J, Zamarreno J, Schiaulini M, Miranda C, et al. CTL responses of high functional avidity and broad variant cross-reactivity are associated with HIV control. PLoS One (2012) 7:e29717. doi:10.1371/ journal.pone.0029717

50. Yang OO, Sarkis PT, Trocha A, Kalams SA, Johnson RP, Walker BD. Impacts of avidity and specificity on the antiviral efficiency of HIV-1-specific CTL. J Immunol (2003) 171:3718-24. doi:10.4049/jimmunol.171.7.3718

51. Autran B, Descours B, Avettand-Fenoel V, Rouzioux C. Elite controllers as a model of functional cure. Curr Opin HIV AIDS (2011) 6:181-7. doi:10.1097/ COH.0b013e328345a328

52. Ho YC, Shan L, Hosmane NN, Wang J, Laskey SB, Rosenbloom DI, et al. Replication-competent noninduced proviruses in the latent reservoir increase barrier to HIV-1 cure. Cell (2013) 155:540-51. doi:10.1016/j.cell.2013.09.020

53. Hegedus A, Kavanagh Williamson M, Huthoff H. HIV-1 pathogenicity and virion production are dependent on the metabolic phenotype of activated CD4+ T cells. Retrovirology (2014) 11:98. doi:10.1186/s12977-014-0098-4

54. Chomont N, DaFonseca S, Vandergeeten C, Ancuta P, Sekaly RP. Maintenance of CD4+ T-cell memory and HIV persistence: keeping memory, keeping HIV. Curr Opin HIV AIDS (2011) 6:30-6. doi:10.1097/COH.0b013e3283413775

55. Pace MJ, Graf EH, Agosto LM, Mexas AM, Male F, Brady T, et al. Directly infected resting CD4+T cells can produce HIV Gag without spreading infection in a model of HIV latency. PLoS Pathog (2012) 8:e1002818. doi:10.1371/ journal.ppat.1002818

56. Ramji R, Wong VC, Chavali AK, Gearhart LM, Miller-Jensen K. A passive-flow microfluidic device for imaging latent HIV activation dynamics in single T cells. Integr Biol (Camb) (2015) 7:998-1010. doi:10.1039/c5ib00094g

57. Badley AD, Sainski A, Wightman F, Lewin SR. Altering cell death pathways as an approach to cure HIV infection. Cell Death Dis (2013) 4:e718. doi:10.1038/ cddis.2013.248

58. Dinter J, Duong E, Lai NY, Berberich MJ, Kourjian G, Bracho-Sanchez E, et al. Variable processing and cross-presentation of HIV by dendritic cells and macrophages shapes CTL immunodominance and immune escape. PLoS Pathog (2015) 11:e1004725. doi:10.1371/journal.ppat.1004725

59. Dinter J, Gourdain P, Lai NY, Duong E, Bracho-Sanchez E, Rucevic M, et al. Different antigen-processing activities in dendritic cells, macrophages, and monocytes lead to uneven production of HIV epitopes and affect CTL recognition. J Immunol (2014) 193:4322-34. doi:10.4049/jimmunol.1400491

60. Lazaro E, Godfrey SB, Stamegna P, Ogbechie T, Kerrigan C, Zhang M, et al. Differential HIV epitope processing in monocytes and CD4 T cells affects cytotoxic T lymphocyte recognition. J Infect Dis (2009) 200:236-43. doi:10.1086/599837

61. Tenzer S, Wee E, Burgevin A, Stewart-Jones G, Friis L, Lamberth K, et al. Antigen processing influences HIV-specific cytotoxic T lymphocyte immunodominance. Nat Immunol (2009) 10:636-46. doi:10.1038/ni.1728

62. Hersperger AR, Pereyra F, Nason M, Demers K, Sheth P, Shin LY, et al. Perforin expression directly ex vivo by HIV-specific CD8 T-cells is a correlate of HIV elite control. PLoS Pathog (2010) 6:e1000917. doi:10.1371/journal. ppat.1000917

63. Makedonas G, Hutnick N, Haney D, Amick AC, Gardner J, Cosma G, et al. Perforin and IL-2 upregulation define qualitative differences among highly functional virus-specific human CD8 T cells. PLoS Pathog (2010) 6:e1000798. doi:10.1371/journal.ppat.1000798

64. Wolint P, Betts MR, Koup RA, Oxenius A. Immediate cytotoxicity but not degranulation distinguishes effector and memory subsets of CD8+ T cells. $J$ Exp Med (2004) 199:925-36. doi:10.1084/jem.20031799

65. Connick E, Mattila T, Folkvord JM, Schlichtemeier R, Meditz AL, Ray MG, et al. CTL fail to accumulate at sites of HIV-1 replication in lymphoid tissue. J Immunol (2007) 178:6975-83. doi:10.4049/jimmunol.178.11.6975

66. Pantaleo G, Graziosi C, Demarest JF, Cohen OJ, Vaccarezza M, Gantt K, et al. Role of lymphoid organs in the pathogenesis of human immunodeficiency virus (HIV) infection. Immunol Rev (1994) 140:105-30. doi:10.1111/j.1600065X.1994.tb00867.x

67. Kuchroo VK, Anderson AC, Petrovas C. Coinhibitory receptors and CD8 T cell exhaustion in chronic infections. Curr Opin HIV AIDS (2014) 9:439-45. doi:10.1097/COH.0000000000000088

68. Porichis F, Kaufmann DE. Role of PD-1 in HIV pathogenesis and as target for therapy. Curr HIV/AIDS Rep (2012) 9:81-90. doi:10.1007/s11904-011-0106-4

69. Hatano H, Yukl SA, Ferre AL, Graf EH, Somsouk M, Sinclair E, et al. Prospective antiretroviral treatment of asymptomatic, HIV-1 infected controllers. PLoS Pathog (2013) 9:e1003691. doi:10.1371/journal.ppat.1003691 
70. Topalian SL, Drake CG, Pardoll DM. Immune checkpoint blockade: a common denominator approach to cancer therapy. Cancer Cell (2015) 27:450-61. doi:10.1016/j.ccell.2015.03.001

71. Wightman F, Solomon A, Kumar SS, Urriola N, Gallagher K, Hiener B, et al. Effect of ipilimumab on the HIV reservoir in an HIV-infected individual with metastatic melanoma. AIDS (2015) 29:504-6. doi:10.1097/ QAD.0000000000000562

72. Velu V, Titanji K, Zhu B, Husain S, Pladevega A, Lai L, et al. Enhancing SIV-specific immunity in vivo by PD-1 blockade. Nature (2009) 458:206-10. doi:10.1038/nature07662

73. Finnefrock AC, Tang A, Li F, Freed DC, Feng M, Cox KS, et al. PD-1 blockade in rhesus macaques: impact on chronic infection and prophylactic vaccination. J Immunol (2009) 182:980-7. doi:10.4049/jimmunol.182.2.980

74. Velu V, Shetty RD, Larsson M, Shankar EM. Role of PD-1 co-inhibitory pathway in HIV infection and potential therapeutic options. Retrovirology (2015) 12:14. doi:10.1186/s12977-015-0144-x

75. Woan KV, Sahakian E, Sotomayor EM, Seto E, Villagra A. Modulation of antigen-presenting cells by HDAC inhibitors: implications in autoimmunity and cancer. Immunol Cell Biol (2012) 90:55-65. doi:10.1038/icb.2011.96

76. Suliman BA, Xu D, Williams BR. HDACi: molecular mechanisms and therapeutic implications in the innate immune system. Immunol Cell Biol (2012) 90:23-32. doi:10.1038/icb.2011.92

77. Jones RB, O'Connor R, Mueller S, Foley M, Szeto GL, Karel D, et al. Histone deacetylase inhibitors impair the elimination of HIV-infected cells by cytotoxic T-lymphocytes. PLoS Pathog (2014) 10:e1004287. doi:10.1371/journal. ppat. 1004287

78. Carlson JM, Le AQ, Shahid A, Brumme ZL. HIV-1 adaptation to HLA: a window into virus-host immune interactions. Trends Microbiol (2015) 23:212-24. doi:10.1016/j.tim.2014.12.008

79. Kirchhoff F. Immune evasion and counteraction of restriction factors by HIV-1 and other primate lentiviruses. Cell Host Microbe (2010) 8:55-67. doi:10.1016/j.chom.2010.06.004

80. Brumme ZL, Brumme CJ, Heckerman D, Korber BT, Daniels M, Carlson J, et al. Evidence of differential HLA class I-mediated viral evolution in functional and accessory/regulatory genes of HIV-1. PLoS Pathog (2007) 3:e94. doi:10.1371/journal.ppat.0030121

81. Moore CB, John M, James IR, Christiansen FT, Witt CS, Mallal SA. Evidence of HIV-1 adaptation to HLA-restricted immune responses at a population level. Science (2002) 296:1439-43. doi:10.1126/science.1069660

82. Price DA, Goulder PJ, Klenerman P, Sewell AK, Easterbrook PJ, Troop M, et al. Positive selection of HIV-1 cytotoxic T lymphocyte escape variants during primary infection. Proc Natl Acad Sci U S A (1997) 94:1890-5. doi:10.1073/pnas.94.5.1890

83. Borrow P, Lewicki H, Wei X, Horwitz MS, Peffer N, Meyers H, et al. Antiviral pressure exerted by HIV-1-specific cytotoxic T lymphocytes (CTLs) during primary infection demonstrated by rapid selection of CTL escape virus. Nat Med (1997) 3:205-11. doi:10.1038/nm0297-205

84. Goonetilleke N, Liu MK, Salazar-Gonzalez JF, Ferrari G, Giorgi E, Ganusov $\mathrm{VV}$, et al. The first $\mathrm{T}$ cell response to transmitted/founder virus contributes to the control of acute viremia in HIV-1 infection. J Exp Med (2009) 206:1253-72. doi:10.1084/jem.20090365

85. Henn MR, Boutwell CL, Charlebois P, Lennon NJ, Power KA, Macalalad $\mathrm{AR}$, et al. Whole genome deep sequencing of HIV-1 reveals the impact of early minor variants upon immune recognition during acute infection. PLoS Pathog (2012) 8:e1002529. doi:10.1371/journal.ppat.1002529

86. Martin E, Carlson JM, Le AQ, Chopera DR, McGovern R, Rahman MA, et al. Early immune adaptation in HIV-1 revealed by population-level approaches. Retrovirology (2014) 11:64. doi:10.1186/s12977-014-0064-1

87. Whitney JB, Hill AL, Sanisetty S, Penaloza-MacMaster P, Liu J, Shetty M, et al. Rapid seeding of the viral reservoir prior to SIV viraemia in rhesus monkeys. Nature (2014) 512:74-7. doi:10.1038/nature13594

88. Deng K, Pertea M, Rongvaux A, Wang L, Durand CM, Ghiaur G, et al. Broad CTL response is required to clear latent HIV-1 due to dominance of escape mutations. Nature (2015) 517:381-5. doi:10.1038/nature14053

89. Sung JA, Lam S, Garrido C, Archin N, Rooney CM, Bollard CM, et al. Expanded cytotoxic T-cell lymphocytes target the latent HIV reservoir. $J$ Infect Dis (2015) 212:258-63. doi:10.1093/infdis/jiv022

90. Hancock G, Yang H, Yorke E, Wainwright E, Bourne V, Frisbee A, et al. Identification of effective subdominant anti-HIV-1 CD8 $+\mathrm{T}$ cells within entire post-infection and post-vaccination immune responses. PLoS Pathog (2015) 11:e1004658. doi:10.1371/journal.ppat.1004658

91. Lima VD, Hogg RS, Harrigan PR, Moore D, Yip B, Wood E, et al. Continued improvement in survival among HIV-infected individuals with newer forms of highly active antiretroviral therapy. AIDS (2007) 21:685-92. doi:10.1097/ QAD.0b013e32802ef30c

92. Grinsztejn B, Hosseinipour MC, Ribaudo HJ, Swindells S, Eron J, Chen YQ, et al. Effects of early versus delayed initiation of antiretroviral treatment on clinical outcomes of HIV-1 infection: results from the phase 3 HPTN 052 randomised controlled trial. Lancet Infect Dis (2014) 14:281-90. doi:10.1016/ S1473-3099(13)70692-3

93. NIAID/NIH. Starting Antiretroviral Treatment Early Improves Outcomes for HIV-infected Individuals. Bethesda, MD: National Institutes of Health (2015).

94. Montaner JS. Treatment as prevention: toward an AIDS-free generation. Top Antivir Med (2013) 21:110-4. http://www.iasusa.org/sites/default/files/ tam/21-3-110.pdf

95. Cohen MS, Chen YQ, McCauley M, Gamble T, Hosseinipour MC, Kumarasamy N, et al. Prevention of HIV-1 infection with early antiretroviral therapy. N Engl J Med (2011) 365:493-505. doi:10.1056/NEJMoa1105243

96. Deeks S. Towards an HIV cure. J Int AIDS Soc (2014) 17:19479. doi:10.7448/ IAS.17.4.19479

97. Jain V, Hartogensis W, Bacchetti P, Hunt PW, Hatano H, Sinclair E, et al. Antiretroviral therapy initiated within 6 months of HIV infection is associated with lower T-cell activation and smaller HIV reservoir size. J Infect Dis (2013) 208:1202-11. doi:10.1093/infdis/jit311

98. Buzon MJ, Martin-Gayo E, Pereyra F, Ouyang Z, Sun H, Li JZ, et al. Longterm antiretroviral treatment initiated at primary HIV-1 infection affects the size, composition, and decay kinetics of the reservoir of HIV-1-infected CD4 T cells. J Virol (2014) 88:10056-65. doi:10.1128/JVI.01046-14

99. Cheret A, Bacchus-Souffan C, Avettand-Fenoel V, Melard A, Nembot G, Blanc C, et al. Combined ART started during acute HIV infection protects central memory CD4+ $\mathrm{T}$ cells and can induce remission. $J$ Antimicrob Chemother (2015) 70:2108-20. doi:10.1093/jac/dkv084

100. Collins KL, Chen BK, Kalams SA, Walker BD, Baltimore D. HIV-1 Nef protein protects infected primary cells against killing by cytotoxic T lymphocytes. Nature (1998) 391:397-401. doi:10.1038/34929

101. Schwartz O, Marechal V, Le Gall S, Lemonnier F, Heard JM. Endocytosis of major histocompatibility complex class I molecules is induced by the HIV-1 Nef protein. Nat Med (1996) 2:338-42. doi:10.1038/nm0396-338

102. Chen DY, Balamurugan A, Ng HL, Cumberland WG, Yang OO. Epitope targeting and viral inoculum are determinants of Nef-mediated immune evasion of HIV-1 from cytotoxic T lymphocytes. Blood (2012) 120:100-11. doi:10.1182/blood-2012-02-409870

103. Balamurugan A, Ali A, Boucau J, Le Gall S, Ng HL, Yang OO. HIV-1 gag cytotoxic $\mathrm{T}$ lymphocyte epitopes vary in presentation kinetics relative to HLA class I downregulation. J Virol (2013) 87:8726-34. doi:10.1128/ JVI.01040-13

104. Sacha JB, Chung C, Rakasz EG, Spencer SP, Jonas AK, Bean AT, et al. Gagspecific CD8+ T lymphocytes recognize infected cells before AIDS-virus integration and viral protein expression. JImmunol (2007) 178:2746-54. doi:10.4049/jimmunol.178.5.2746

105. Kiepiela P, Ngumbela K, Thobakgale C, Ramduth D, Honeyborne I, Moodley E, et al. CD8+ T-cell responses to different HIV proteins have discordant associations with viral load. Nat Med (2007) 13:46-53. doi:10.1038/nm1520

106. Adland E, Carlson JM, Paioni P, Kloverpris H, Shapiro R, Ogwu A, et al. Nef-specific CD8+ T cell responses contribute to HIV-1 immune control. PLoS One (2013) 8:e73117. doi:10.1371/journal.pone.0073117

107. Ensoli F, Cafaro A, Casabianca A, Tripiciano A, Bellino S, Longo O, et al. HIV-1 Tat immunization restores immune homeostasis and attacks the HAARTresistant blood HIV DNA: results of a randomized phase II exploratory clinical trial. Retrovirology (2015) 12:33. doi:10.1186/s12977-015-0151-y

108. Rajapaksa US, Li D, Peng YC, McMichael AJ, Dong T, Xu XN. HLA-B may be more protective against HIV-1 than HLA-A because it resists negative regulatory factor (Nef) mediated down-regulation. Proc Natl Acad Sci U S A (2012) 109:13353-8. doi:10.1073/pnas.1204199109

109. Le Gall S, Erdtmann L, Benichou S, Berlioz-Torrent C, Liu L, Benarous $\mathrm{R}$, et al. Nef interacts with the mu subunit of clathrin adaptor complexes and reveals a cryptic sorting signal in MHC I molecules. Immunity (1998) 8:483-95. doi:10.1016/S1074-7613(00)80553-1 
110. Cohen GB, Gandhi RT, Davis DM, Mandelboim O, Chen BK, Strominger JL, et al. The selective downregulation of class I major histocompatibility complex proteins by HIV-1 protects HIV-infected cells from NK cells. Immunity (1999) 10:661-71. doi:10.1016/S1074-7613(00)80065-5

111. Apps R, Qi Y, Carlson JM, Chen H, Gao X, Thomas R, et al. Influence of HLA-C expression level on HIV control. Science (2013) 340:87-91. doi:10.1126/science. 1232685

112. Pham TN, Lukhele S, Hajjar F, Routy JP, Cohen EA. HIV Nef and Vpu protect HIV-infected CD4+ $\mathrm{T}$ cells from antibody-mediated cell lysis through down-modulation of CD4 and BST2. Retrovirology (2014) 11:15. doi:10.1186/1742-4690-11-15

113. Veillette M, Coutu M, Richard J, Batraville LA, Dagher O, Bernard N, et al. The HIV-1 gp120 CD4-bound conformation is preferentially targeted by antibody-dependent cellular cytotoxicity-mediating antibodies in sera from HIV-1-infected individuals. J Virol (2015) 89:545-51. doi:10.1128/ JVI.02868-14

114. Veillette M, Desormeaux A, Medjahed H, Gharsallah NE, Coutu M, Baalwa J, et al. Interaction with cellular CD4 exposes HIV-1 envelope epitopes targeted by antibody-dependent cell-mediated cytotoxicity. J Virol (2014) 88:2633-44. doi:10.1128/JVI.03230-13

115. Mwimanzi P, Markle TJ, Martin E, Ogata Y, Kuang XT, Tokunaga M, et al. Attenuation of multiple Nef functions in HIV-1 elite controllers. Retrovirology (2013) 10:1. doi:10.1186/1742-4690-10-1

116. Mann JK, Byakwaga H, Kuang XT, Le AQ, Brumme CJ, Mwimanzi P, et al. Ability of HIV-1 Nef to downregulate CD4 and HLA class I differs among viral subtypes. Retrovirology (2013) 10:100. doi:10.1186/1742-4690-10-100

117. Kuang XT, Li X, Anmole G, Mwimanzi P, Shahid A, Le AQ, et al. Impaired Nef function is associated with early control of HIV-1 viremia. J Virol (2014) 88:10200-13. doi:10.1128/JVI.01334-14

118. Smithgall TE, Thomas G. Small molecule inhibitors of the HIV-1 virulence factor, Nef. Drug Discov Today Technol (2013) 10:e523-9. doi:10.1016/j. ddtec.2013.07.002

119. Bruner KM, Hosmane NN, Siliciano RF. Towards an HIV-1 cure: measuring the latent reservoir. Trends Microbiol (2015) 23:192-203. doi:10.1016/j. tim.2015.01.013

120. Gill VS, Lima VD, Zhang W, Wynhoven B, Yip B, Hogg RS, et al. Improved virological outcomes in British Columbia concomitant with decreasing incidence of HIV type 1 drug resistance detection. Clin Infect Dis (2010) 50:98-105. doi:10.1086/648729

121. Rhee SY, Blanco JL, Jordan MR, Taylor J, Lemey P, Varghese V, et al. Geographic and temporal trends in the molecular epidemiology and genetic mechanisms of transmitted HIV-1 drug resistance: an individual-patient- and sequence-level meta-analysis. PLoS Med (2015) 12:e1001810. doi:10.1371/ journal.pmed.1001810

122. Brumme ZL, Brumme CJ, Carlson J, Streeck H, John M, Eichbaum Q, et al. Marked epitope- and allele-specific differences in rates of mutation in human immunodeficiency type 1 (HIV-1) Gag, Pol, and Nef cytotoxic T-lymphocyte epitopes in acute/early HIV-1 infection. J Virol (2008) 82:9216-27. doi:10.1128/JVI.01041-08

123. Fischer W, Ganusov VV, Giorgi EE, Hraber PT, Keele BF, Leitner T, et al. Transmission of single HIV-1 genomes and dynamics of early immune escape revealed by ultra-deep sequencing. PLoS One (2010) 5:e12303. doi:10.1371/ journal.pone. 0012303

124. Reece J, Petravic J, Balamurali M, Loh L, Gooneratne S, De Rose R, et al. An "escape clock" for estimating the turnover of SIV DNA in resting CD4(+) T cells. PLoS Pathog (2012) 8:e1002615. doi:10.1371/journal.ppat.1002615

125. Reece JC, Martyushev A, Petravic J, Grimm A, Gooneratne S, Amaresena $\mathrm{T}$, et al. Measuring turnover of SIV DNA in resting CD4+ T cells using pyrosequencing: implications for the timing of HIV eradication therapies. PLoS One (2014) 9:e93330. doi:10.1371/journal.pone.0093330

126. Shapiro B, Ho SY, Drummond AJ, Suchard MA, Pybus OG, Rambaut AA. Bayesian phylogenetic method to estimate unknown sequence ages. Mol Biol Evol (2011) 28:879-87. doi:10.1093/molbev/msq262

127. Korber B, Muldoon M, Theiler J, Gao F, Gupta R, Lapedes A, et al. Timing the ancestor of the HIV-1 pandemic strains. Science (2000) 288:1789-96. doi:10.1126/science.288.5472.1789

128. Worobey M, Gemmel M, Teuwen DE, Haselkorn T, Kunstman K, Bunce M, et al. Direct evidence of extensive diversity of HIV-1 in Kinshasa by 1960 . Nature (2008) 455:661-4. doi:10.1038/nature07390
129. Poon AF, Swenson LC, Bunnik EM, Edo-Matas D, Schuitemaker H, van 't Wout AB, et al. Reconstructing the dynamics of HIV evolution within hosts from serial deep sequence data. PLoS Comput Biol (2012) 8:e1002753. doi:10.1371/journal.pcbi.1002753

130. Mylvaganam GH, Silvestri G, Amara RR. HIV therapeutic vaccines: moving towards a functional cure. Curr Opin Immunol (2015) 35:1-8. doi:10.1016/j. coi.2015.05.001

131. Mylvaganam GH, Velu V, Hong JJ, Sadagopal S, Kwa S, Basu R, et al. Diminished viral control during simian immunodeficiency virus infection is associated with aberrant PD-1hi CD4 T cell enrichment in the lymphoid follicles of the rectal mucosa. J Immunol (2014) 193:4527-36. doi:10.4049/ jimmunol.1401222

132. Perreau M, Savoye AL, De Crignis E, Corpataux JM, Cubas R, Haddad EK, et al. Follicular helper $\mathrm{T}$ cells serve as the major $\mathrm{CD} 4 \mathrm{~T}$ cell compartment for HIV-1 infection, replication, and production. J Exp Med (2013) 210:143-56. doi:10.1084/jem.20121932

133. Xu Y, Weatherall C, Bailey M, Alcantara S, De Rose R, Estaquier J, et al. Simian immunodeficiency virus infects follicular helper CD4 T cells in lymphoid tissues during pathogenic infection of pigtail macaques. J Virol (2013) 87:3760-73. doi:10.1128/JVI.02497-12

134. Santangelo PJ, Rogers KA, Zurla C, Blanchard EL, Gumber S, Strait K, et al. Whole-body immunoPET reveals active SIV dynamics in viremic and antiretroviral therapy-treated macaques. Nat Methods (2015) 12:427-32. doi: $10.1038 /$ nmeth.3320

135. Haynes BF. New approaches to HIV vaccine development. Curr Opin Immunol (2015) 35:39-47. doi:10.1016/j.coi.2015.05.007

136. Hansen SG, Ford JC, Lewis MS, Ventura AB, Hughes CM, Coyne-Johnson L, et al. Profound early control of highly pathogenic SIV by an effector memory T-cell vaccine. Nature (2011) 473:523-7. doi:10.1038/nature10003

137. Hansen SG, Piatak M Jr, Ventura AB, Hughes CM, Gilbride RM, Ford JC, et al. Immune clearance of highly pathogenic SIV infection. Nature (2013) 502:100-4. doi:10.1038/nature12519

138. Hansen SG, Sacha JB, Hughes CM, Ford JC, Burwitz BJ, Scholz I, et al. Cytomegalovirus vectors violate $\mathrm{CD} 8+\mathrm{T}$ cell epitope recognition paradigms. Science (2013) 340:1237874. doi:10.1126/science.1237874

139. Lizee G, Overwijk WW, Radvanyi L, Gao J, Sharma P, Hwu P. Harnessing the power of the immune system to target cancer. Annu Rev Med (2013) 64:71-90. doi:10.1146/annurev-med-112311-083918

140. Leibman RS, Riley JL. Engineering T cells to functionally cure HIV-1 infection. Mol Ther (2015) 23:1149-59. doi:10.1038/mt.2015.70

141. Scholler J, Brady TL, Binder-Scholl G, Hwang WT, Plesa G, Hege KM, et al. Decade-long safety and function of retroviral-modified chimeric antigen receptor T cells. Sci Transl Med (2012) 4:132ra153. doi:10.1126/ scitranslmed.3003761

142. Cruz CR, Hanley PJ, Liu H, Torrano V, Lin YF, Arce JA, et al. Adverse events following infusion of $\mathrm{T}$ cells for adoptive immunotherapy: a 10-year experience. Cytotherapy (2010) 12:743-9. doi: $10.3109 / 14653241003709686$

143. Lam S, Bollard C. T-cell therapies for HIV. Immunother (2013) 5:407-14. doi:10.2217/imt.13.23

144. Brodie SJ, Lewinsohn DA, Patterson BK, Jiyamapa D, Krieger J, Corey L, et al. In vivo migration and function of transferred HIV-1-specific cytotoxic T cells. Nat Med (1999) 5:34-41. doi:10.1038/4716

145. Chapuis AG, Casper C, Kuntz S, Zhu J, Tjernlund A, Diem K, et al. HIVspecific CD8+ T cells from HIV+ individuals receiving HAART can be expanded ex vivo to augment systemic and mucosal immunity in vivo. Blood (2011) 117:5391-402. doi:10.1182/blood-2010-11-320226

146. Koenig S, Conley AJ, Brewah YA, Jones GM, Leath S, Boots LJ, et al. Transfer of HIV-1-specific cytotoxic T lymphocytes to an AIDS patient leads to selection for mutant HIV variants and subsequent disease progression. Nat Med (1995) 1:330-6. doi:10.1038/nm0495-330

147. Lieberman J, Skolnik PR, Parkerson GR III, Fabry JA, Landry B, Bethel J, et al. Safety of autologous, ex vivo-expanded human immunodeficiency virus (HIV)-specific cytotoxic T-lymphocyte infusion in HIV-infected patients. Blood (1997) 90:2196-206.

148. Riddell SR, Elliott M, Lewinsohn DA, Gilbert MJ, Wilson L, Manley SA, et al. T-cell mediated rejection of gene-modified HIV-specific cytotoxic T lymphocytes in HIV-infected patients. Nat Med (1996) 2:216-23. doi:10.1038/ nm0296-216 
149. Hinrichs CS, Rosenberg SA. Exploiting the curative potential of adoptive T-cell therapy for cancer. Immunol Rev (2014) 257:56-71. doi:10.1111/imr.12132

150. Phan GQ, Rosenberg SA. Adoptive cell transfer for patients with metastatic melanoma: the potential and promise of cancer immunotherapy. Cancer Control (2013) 20:289-97. https://www.moffitt.org/File\%20 Library/Main\%20Nav/Research\%20and\%20Clinical\%20Trials/Cancer\%20 Control\%20Journal/v20n4/289.pdf

151. Lam S, Sung J, Cruz C, Castillo-Caro P, Ngo M, Garrido C, et al. Broadlyspecific cytotoxic T cells targeting multiple HIV antigens are expanded from HIV+ patients: implications for immunotherapy. Mol Ther (2015) 23:387-95. doi:10.1038/mt.2014.207

152. Kitchen SG, Levin BR, Bristol G, Rezek V, Kim S, Aguilera-Sandoval C, et al. In vivo suppression of HIV by antigen specific $\mathrm{T}$ cells derived from engineered hematopoietic stem cells. PLoS Pathog (2012) 8:e1002649. doi:10.1371/journal.ppat.1002649

153. Zhen A, Kamata M, Rezek V, Rick J, Levin B, Kasparian S, et al. HIV-specific immunity derived from chimeric antigen receptor-engineered stem cells. Mol Ther (2015) 23:1358-67. doi:10.1038/mt.2015.102

154. Liu L, Patel B, Ghanem MH, Bundoc V, Zheng Z, Morgan RA, et al. Novel CD4-based bispecific chimeric antigen receptor designed for enhanced
anti-HIV potency and absence of HIV entry receptor activity. $J$ Virol (2015) 89:6685-94. doi:10.1128/JVI.00474-15

155. Varela-Rohena A, Molloy PE, Dunn SM, Li Y, Suhoski MM, Carroll RG, et al. Control of HIV-1 immune escape by CD8 T cells expressing enhanced T-cell receptor. Nat Med (2008) 14:1390-5. doi:10.1038/nm.1779

156. Linette GP, Stadtmauer EA, Maus MV, Rapoport AP, Levine BL, Emery L, et al. Cardiovascular toxicity and titin cross-reactivity of affinity-enhanced T cells in myeloma and melanoma. Blood (2013) 122:863-71. doi:10.1182/ blood-2013-03-490565

Conflict of Interest Statement: The authors declare that the research was conducted in the absence of any commercial or financial relationships that could be construed as a potential conflict of interest.

Copyright (c) 2015 Brockman, Jones and Brumme. This is an open-access article distributed under the terms of the Creative Commons Attribution License (CC BY). The use, distribution or reproduction in other forums is permitted, provided the original author(s) or licensor are credited and that the original publication in this journal is cited, in accordance with accepted academic practice. No use, distribution or reproduction is permitted which does not comply with these terms. 